\title{
HYPOCHOLESTEROLEMIC EFFECT OF SAPONIN EXTRACTS IN EXPERIMENTAL ANIMALS
}

\author{
Amany M.M. Ali*, Tawfik M.F., Hikal M.S. and Tag El-Din M.A. \\ Agric. Biochemistry Dept., Fac. of Agric., Ain Shams Univ., P.O. Box 68, Hadayek Shobra \\ 11241, Cairo, Egypt \\ *Corresponding author: Amany.mohamed.am23@gmail.com
}

Accepted 15 August, 2018

\section{ABSTRACT}

Hypercholesterolemia was induced by feeding of rats on a high cholesterol diet (HCD) that contains cholesterol $(1 \%)$, bile salts $(0.25 \%)$ and coconut butter $(15 \%)$ to evaluate the protective effect of steroidal saponins extracted from fenugreek and asparagus, and triterpenoidal saponins extracted from soapwort and licorice. The rats were divided into 6 groups, and the first one was fed on a basal diet and served as a negative control group. The second group of rats received HCD without any plant extract and served as a positive control group. The other four groups of rats were fed on HCD plus the plant extracts separately at a dose of $250 \mathrm{mg} / \mathrm{kg} /$ day during the experiment period (6 weeks). The protective effect of various saponin extracts were monitored through assays of total cholesterol (TC) and triglycerides (TG) in blood, liver tissues and feces of the rats as well as other blood analyses and histological examinations of liver tissues. The data indicated a significant $(P<0.05)$ increase in the levels of TC, TG, low density lipoprotein (LDL), very low density lipoprotein (VLDL), creatine phosphokinase (CPK), lactate dehydrogenase (LDH), alanine aminotransferase (ALT), aspartate aminotransferase (AST), alkaline phosphatase (ALP), gamma glutamyltransferase (GGT) and glucose, and a significant $(P<0.05)$ decrease in the level of high density lipoprotein $(\mathrm{HDL})$ in addition to insignificant $(\mathrm{P}<0.05)$ differences in the levels of total bilirubin (TB), total protein (TP), urea, creatinine and uric acid in serum of hypercholesterolemic rats (the positive control) compared to the negative control. The protective effect of various saponin extracts were established by lowering the levels of TC and TG, and obtaining the other biochemical parameters near to their normal values in serum of rats fed on these plant extracts. The data also indicate that $\mathrm{TC}$ and $\mathrm{TG}$ decreased significantly $(P<0.05)$ in liver tissues of the rats treated with various saponin extracts compared to the positive control. Conversely, the levels of $T C$ and $T G$ increased significantly $(P<0.05)$ in feces of the rats treated with various saponin extracts compared to the negative and positive controls. Histological examinations showed lower content of fats in liver tissues of the rats treated with various saponin extracts compared to the positive control. Both of steroidal and triterpenoidal saponins exhibited approximately the same efficiency in their protective effects against hypercholesterolemia. The hypocholesterolemic effect of saponin extracts may be due to the inhibition of cholesterol absorption in the intestine which led to increase of cholesterol excretion in the feces.

Keywords: Asparagus, Fenugreek, Hypercholesterolemia, Licorice, Saponins, Soapwort, Steroidal, Triterpenoidal.

\section{INTRODUCTION}

Hypercholesterolemia, elevated low-density lipoprotein (LDL) cholesterol concentration and hypertriglyceridemia are major risk factors for the development of atherosclerosis and cardiovascular disease. Persistent hypercholesterolemia results from an increase in the production and secretion of LDL that prolongs its period of circulation, which increases oxidative stress and leads to the oxidative modification of LDL to oxidized LDL (VázquezCastilla et al 2013).

Synthetic drugs like statins and fibrates, which reduce the levels of lipids and cholesterol possesses potentially toxic side effects. Viable alterna- 
tives to the synthetic drugs are natural products which exhibit high lipid lowering potential with minimal or no side effects. Earlier studies reveal that the consumption of medicinal plants containing saponins reduces the risk of hypercholesterolemia (Marrelli et al 2016).

Saponins are compounds that occur naturally in many plants and possess detergent-like properties (the name saponin is derived from the word "soap"). Saponins vary in their chemical structures and a large amount of research has been conducted in the last decade to attempt to isolate and identify saponins found in plants. A saponin consists of a hydrophobic nucleus (steroidal or triterpenoid) attached to hydrophilic groups (carbohydrate side chains) (Hostettmann and Marston, 1995). Saponins are generally classified by the chemical structure of their nucleus (aglycone). Thus, there are steroidal saponins and triterpenoid saponins. Although saponins have diverse chemical structures, they possess some common characteristics. Examples of common traits are bitter taste (associated with reduced palatability to some animals), formation of stable foams in aqueous solutions (detergent-like properties), toxicity to mollusks and fish (piscicidal and molluscicidal uses), ability to form complexes with bile acids and cholesterol (Sidhu and Oakenfull, 1986), and interaction with cell membranes (red blood cell hemolysis). Within a plant, high concentrations of saponins tend to be found in the roots and among growing shoots. However, this trend is variable depending on the species of plant. For example, Quillaja saponaria contains high levels of saponins in its bark, while alfalfa in its roots. Saponins have been shown to influence nutrient digestion and absorption in a variety of ways. Mechanisms of action involved in these effects are not clearly defined. It has been determined that saponins form insoluble complexes with cholesterol and inhibit the availability of bile salts (Oakenfull, 1986). These interactions may exert effects on micelle formation and thus, impair the absorption off at and fat-soluble compounds (Jenkins and Atwal, 1994). Saponins possess a wide range of biological activities, one of them being the ability to inhibit cholesterol absorption and to decrease serum and liver cholesterol. The latter effect has important implications for human health, as it could help the battle against hypercholesterolemia and the cardiovascular problems, associated with it (Vinarova et al 2015).

Fenugreek (Trigonella foenum graecum) seed contains alkaloids, flavonoids and saponins but out of all these, saponins are found to be in maximum concentration in the fenugreek (Jani et al 2009; Uemura et al 2011; Kumar et al 2012). Fenugreek seed contains $3.5 \%$ alkaloids, primarily trigonelline, whereas saponin was found to be 4.8\% (Rao et al 1996; Faeste et al 2009; Jani et al 2009). Alkaloids, flavonoids and saponins of fenugreek have pharmacological effects. They act as antilipidemic, hypoglycaemic and cholagogic agent and their use should be promoted to manage diabetes mellitus, hypercholesterolemia because clinical evidence shows promising results in reducing serum cholesterol level (Izzo et al 2005; Murlidhar and Goswami, 2012). Fenugreek seeds have lowered serum cholesterol, triglyceride and low-density lipoprotein in hypercholesterolemia suffering patients and experimental models. Fenugreek consumption in diet reduced triglyceride accumulation in the liver but do not interfered with the plasma insulin or glucose levels obesity suffering rats (Basch et al 2003; Murlidhar and Goswami, 2012).

Asparagus (Asparagus officinalis) shoot contains bioactive constituents such as dietary fiber, polyphenols, saponins, sterols, oligosaccharides, carotenoids and amino acids, all of which may contribute to the functional properties of this vegetable. Among the compounds with antioxidant activity, asparagus contains a large amount of polyphenols, mainly flavonoids. The flavonoid rutin constitutes $60 \%-80 \%$ of the total phenolic content of purple and green asparagus extracts, and rutin could be directly related to the antioxidant properties of asparagus (Vázquez-Castilla et al 2013).

Licorice (Glycyrrhiza glabra) root extract contains saponin, triterpenes (glycyrrhizin, glycyrrhetinic acid and liquirtic acid), flavoniods (liquirtin, isoflavonoids and formononetin) and other constituents such as coumarins, simple sugar and polysaccharide like starch, pectin, amino acids, tannins, choline, phytosterols, mineral salts and various other substance (Fukai et al 1998). The most important compounds are glycyrrhizin and glycyrrhizic acid, which are believed to be partly responsible for anti-ulcer, anti-inflammatory, anti-diuretic, anti-epileptic, anti-hepatotoxic, anti-viral activities, anti-allergic and antioxidant property of the plant as well as their ability to fight low blood pressure (Ross, 2001; Arystanova et al 2001; Al Qarawi et al 2001). The other important compound is glabridin, it is the major flavonoid, present specifically in licorice; it has various physiological activities such as cytotoxic, anti-tumor promoting, antimicrobial, estrogenic and anti-proliferative activity against human breast cancer cells. It also affects 
melanogensis, inflammation, low density lipoprotein (LDL) oxidation and protection of mitochondria functions from oxidative stresses (Khatta and Simpson, 2010).

Soapwort (Saponaria officinalis) extract is obtained by boiling the roots of the soapwort. Saponins (active substance of soapwort extract) are found in the diet, phytochemical saponins have a wide spectrum of activity as antifungal and antibacterial agents, lowering of blood cholesterol and inhibition of cancer cell growth. However, many saponins show haemolytic activity, and have a bitter taste (Ceyhun-Sezgin and Artik, 2010). The cholesterol-lowering activity of saponaria has been demonstrated both in animal studies and in clinical trials with humans. It was proposed that the saponin action must be inside the intestine, because the saponins are not absorbed in the gut. Some saponins (soya, soapwort) inhibit intestinal bile salt (BS) reabsorption via formation of large saponin + BS aggregates, which enhances BS synthesis from cholesterol in the liver and, thus, leads to cholesterol depletion (Vinarova et al 2015).

Therefore, the present study was carried out to evaluate the protective effects of steroidal saponins extracted from fenugreek seeds and asparagus shoots, and triterpenoidal saponins extracted from soapwort and licorice rhizomes against hypercholesterolemia induced by feeding of rats on a high cholesterol diet. The present study was also aimed to compare between the efficacies of both types of saponins (steroidal and triterpenoidal) from these plant extracts against hypercholesterolemia in the rats.

\section{MATERIALS AND METHODS}

\section{Materials}

Fenugreek (Trigonella foenum-graecum) seeds and asparagus shoots (Asparagus officinalis) were obtained from a local market, Cairo, Egypt. Licorice (Glycyrrhiza glabra) and soapwort (Saponaria officinalis) rhizomes were purchased from Agricultural Seeds, Spices and Medicinal Plants Co., AlAzhar St., Cairo, Egypt. All chemicals used in this work were of analytical grade.

\section{Reagent kits}

Triglycerides (TG), total cholesterol (TC), high density lipoprotein (HDL), aspartate aminotransferase (AST), alanine aminotransferase (ALT), gamma glutamyl transferase (GGT), alkaline phospha- tase (ALP), total bilirubin (TB), total protein (TP), urea, creatinine, uric acid, glucose, creatine phosphokinase (CPK) and lactate dehydrogenase (LDH) kits were obtained from Egyptian company for Biotechnology, Obour city, Industrial area, block 20008 pieces 19A. Cairo, Egypt.

\section{Methods}

\section{Preparation of saponin extracts}

Two hundred grams of ground asparagus shoots, licorice, soapwort rhizomes or defatted fenugreek seeds were extracted twice with 2:1 of ethanol $(70 \%)$ for 24 hours at room temperature $\left(25^{\circ} \mathrm{C}\right)$, and the samples were filtered after each extraction. Solvent was removed from the combined extracts with a vacuum rotary evaporator at $40^{\circ} \mathrm{C}$ to obtain crude plant extracts. The dried extracts were weighed and stored at $-20^{\circ} \mathrm{C}$ until use (Senapaty et al 2014).

\section{Biological evaluation \\ Experimental animals}

Thirty six male Albino rats of Wistar strain weighing about $100 \mathrm{~g}$ each were obtained from the farm of experimental animals in Helwan, Cairo, Egypt. The rats were housed under normal laboratory conditions. The rats had free access food and water ad libitum during the experiment period.

\section{Experimental design}

Rats were randomly divided into 6 groups $(n=$ 6 ), and the first one was fed on a basal diet and served as a negative control group. The basal diet was formulated from corn starch $(70 \%)$, casein (10\%), corn oil (10\%), cellulose $(5 \%)$, vitamins and minerals (5\%) according to Reeves et al (1993). The other groups of rats were fed on a high cholesterol diet formulated from cholesterol (1\%), bile salts $(0.25 \%)$ and coconut butter (15\%) instead of equal percentages of corn starch in the basal diet (Zulet et al 1999). The second group of rats received the high cholesterol diet without any plant extract and served as a positive control group. The other four groups of rats were fed on the high cholesterol diet plus various plant extracts during the experiment period (6 weeks). The various plant extracts (fenugreek, asparagus, soapwort and licorice) were administered orally for the rats by using a stomach tube every day at a dose of $250 \mathrm{mg} / \mathrm{kg}$ body weight. 


\section{Blood sampling and biochemical assays}

Blood samples were collected in clean centrifuge tubes from retro-orbital venous plexus of all animals by using capillary tubes. After that, serum was separated from the collected blood samples by centrifugation and kept in a refrigerator at $4{ }^{\circ} \mathrm{C}$ until analysis. Biochemical measurements of AST, ALT (Young, 1990), ALP, CPK (IFCC, 1989), GGT (Persjn and Van der Slik, 1976), LDH (Dito, 1979), Urea (Tietz, 1990), Creatinine (Bowers and Wong, 1980), uric acid (Jung and Parekh, 1970), Total bilirubin (Malloy and Evelyn, 1937), Total protein (Gornall et al 1949), Triglycerides (TG) (Mgowan et al 1983), total cholesterol (TC) (Roeschlau et al 1974), HDL (NCEPR, 1995), LDL (Makni et al 2008), VLDL (Vejtorp et al 1986) and Glucose (Tietz, 1995) were applied.

\section{Determination of cholesterol and triglycerides in liver}

At the end of experiment, the rats were sacrificed and the liver was removed. Total cholesterol and triglycerides were determined in liver according to the method described by Hostmark et al (2010).

\section{Determination of cholesterol and triglycerides in feces}

Rat feces were collected throughout the experiment period to estimate their content of total cholesterol and triglycerides according to the method described by Folch et al (1957).

\section{Histological examination of liver tissues}

At the end of experiment, the rats were sacrificed and the liver was removed and stored in $10 \%$ formalin for histological evaluation according to the method described by Srivastava and Shivanandappa (2006).

\section{Statistical analysis}

The data are presented as means \pm SE of three replicates. The recorded data were treated statistically using the one way analysis of variance (ANOVA). The means were compared by Least Significant Difference test (LSD) at $\mathrm{P}<0.05$. Statistical analyses were performed using SPSS statistical software (IBM SPSS Statistics, version 20) (Snedecor and Cochran, 1980).

\section{RESULTS AND DISCUSSION}

Hypocholesterolemic effect of steroidal saponins (C27) extracted from fenugreek and asparagus, and triterpenoidal saponins (C30) extracted from soapwort and licorice were monitored through assays of total cholesterol (TC) and triglycerides (TG) in blood, liver tissues and feces of the rats as well as other blood biochemical analyses and histological examinations of liver tissues. The obtained data were classified into the following items:

\section{Effect of saponin extracts on the lipid profile in serum of rats affected with hypercholester- olemia}

Table (1) shows the protective effects of steroidal saponins extracted from fenugreek and asparagus, and triterpenoidal saponins extracted from soapwort and licorice on the lipid profile (serum triglycerides and cholesterol fractions) analyzed at the end of experiment (6 weeks) in the rats affected with hypercholesterolemia induced by feeding on high cholesterol diet (HCD). The results showed a significant $(P<0.05)$ increase in the levels of total cholesterol (TC), triglycerides (TG), low density lipoprotein cholesterol (LDL), very low density lipoprotein cholesterol (VLDL), and a significant $(P<0.05)$ decrease in the level of high density lipoprotein cholesterol (HDL) in serum of rats treated with HCD only in positive control group compared to negative control group. This may be due to feeding of rats in the positive control group on HCD that also contains high saturated fat, coconut butter (15\%) besides corn oil (10\%) compared to feeding of rats in the negative control group on a basal diet that contains corn oil $(10 \%)$ only. The protective effects of various saponin extracts were proved by decreasing the levels of TC, TG, LDL and VLDL, and increasing the level of HDL to approach their normal values in serum of rats administered these plant extracts. The lowering effect of saponin extracts against hypertriglyceridemia may be due to their inhibition effect of pancreatic lipase enzyme (Han et al 2002). The lowering effect of saponin extracts against hypercholesterolemia may be due to their inhibition effect of cholesterol absorption from the intestine (Satoskar et al 2003; Vinarova et al 2015). No significant $(P<0.05)$ differences were noticed among the protective effects of all investigated plant extracts against hypercholesterolemia in rats. It means that both types of saponins (steroidal and triterpenoidal) exhibited approximately the same efficiency in their protective effects against hypercholesterolemia. These results are in agreement with those obtained by Afrose et al (2010); Marrelli et al (2016). 
Table 1. Effect of saponin extracts of Trigonella (TRI), Asparagus (ASP), Saponaria (SAP) and Glycyrrhiza (GLY) on the levels of triglycerides and cholesterol fractions in serum of rats treated with high cholesterol diet (HCD)

\begin{tabular}{|c|c|c|c|c|c|c|}
\hline Treatment & Control & HCD only & $\begin{array}{l}\text { HCD } \\
+ \text { TRI }\end{array}$ & $\begin{array}{r}\text { HCD } \\
+ \text { ASP }\end{array}$ & $\begin{array}{r}\text { HCD } \\
+ \text { SAP }\end{array}$ & $\begin{array}{r}\text { HCD } \\
+ \text { GLY }\end{array}$ \\
\hline $\begin{array}{l}\text { Triglycerides } \\
\text { (mg/dl) }\end{array}$ & $\begin{array}{c}98.6 \\
\pm 5.9^{\mathrm{b}}\end{array}$ & $\begin{array}{r}129.3 \\
\pm 2.0^{a}\end{array}$ & $\begin{array}{c}92.4 \\
\pm 2.6^{b}\end{array}$ & $\begin{array}{c}88.6 \\
\pm 3.1^{b}\end{array}$ & $\begin{array}{r}92.2 \\
\pm 7.0^{\mathrm{b}}\end{array}$ & $\begin{array}{r}95.6 \\
\pm 4.8^{b}\end{array}$ \\
\hline $\begin{array}{c}\text { Total } \\
\text { cholesterol } \\
(\mathrm{mg} / \mathrm{dl})\end{array}$ & $\begin{array}{l}64.3 \\
\pm 4.9^{\mathrm{b}}\end{array}$ & $\begin{array}{r}148.7 \\
\pm 1.4^{a}\end{array}$ & $\begin{array}{c}58.3 \\
\pm 2.9^{b}\end{array}$ & $\begin{array}{r}59.6 \\
\pm 3.4^{b}\end{array}$ & $\begin{array}{r}64.6 \\
\pm 3.1^{\mathrm{b}}\end{array}$ & $\begin{aligned} & 67.6 \\
\pm & 0.8^{b}\end{aligned}$ \\
\hline $\begin{array}{c}\text { HDL } \\
(\mathrm{mg} / \mathrm{dl})\end{array}$ & $\begin{array}{r}36.8 \\
\pm 3.8^{a}\end{array}$ & $\begin{array}{r}13.5 \\
\pm 1.5^{b}\end{array}$ & $\begin{array}{c}37.1 \\
\pm 3.5^{a}\end{array}$ & $\begin{array}{r}35.8 \\
\pm 3.9^{a}\end{array}$ & $\begin{array}{c}37.1 \\
\pm 3.9^{a}\end{array}$ & $\begin{array}{c}38.1 \\
\pm 3.7^{a}\end{array}$ \\
\hline $\begin{array}{l}\text { LDL } \\
(\mathrm{mg} / \mathrm{dl})\end{array}$ & $\begin{array}{r}8.3 \\
\pm 2.1^{\mathrm{b}}\end{array}$ & $\begin{array}{r}115.3 \\
\pm 1.8^{a}\end{array}$ & $\begin{array}{c}6 \\
\pm 0.8^{b}\end{array}$ & $\begin{aligned} & 7.8 \\
\pm & 0.3^{b}\end{aligned}$ & $\begin{array}{r}9.12 \\
\pm 3.1^{\mathrm{b}}\end{array}$ & $\begin{aligned} & 10.4 \\
\pm & 2.0^{\mathrm{b}}\end{aligned}$ \\
\hline $\begin{array}{l}\text { VLDL } \\
(\mathrm{mg} / \mathrm{dl})\end{array}$ & $\begin{array}{r}19.7 \\
\pm 1.1^{\mathrm{b}} \\
\end{array}$ & $\begin{array}{r}25.8 \\
\pm 0.4^{a}\end{array}$ & $\begin{array}{c}18.4 \\
\pm 0.5^{b}\end{array}$ & $\begin{array}{r}17.7 \\
\pm 0.6^{\mathrm{b}}\end{array}$ & $\begin{array}{r}18.4 \\
\pm 1.4^{\mathrm{b}}\end{array}$ & $\begin{array}{c}19.1 \\
\pm 0.9^{\mathrm{b}}\end{array}$ \\
\hline
\end{tabular}

The data are presented as means \pm SE calculated from three replicates.

Different letters refer to significant differences at $(P<0.05)$.

\section{Effect of saponin extracts on the lipid profile in liver of rats affected with hypercholesterol- emia}

Table (2) reveals the protective effects of steroidal saponins extracted from fenugreek and asparagus, and triterpenoidal saponins extracted from soapwort and licorice on the lipid profile (total cholesterol and triglycerides) in liver of rats affected with hypercholesterolemia induced by feeding on high cholesterol diet (HCD). The results revealed a significant $(P<0.05)$ increase in the levels of total cholesterol (TC) and triglycerides (TG) in liver of rats treated with HCD only in positive control group compared to negative control group. This may be ascribed to feeding of rats in the positive control group on HCD that also contains high saturated fat (coconut butter) compared to feeding of rats in the negative control group on a normal diet containing corn oil. The protective effects of various saponin extracts were established by obtaining the levels of TC and TG near to their normal values in liver of rats administered these plant extracts. These results are in agreement with those obtained by Shi et al (2014) who found that administration of alfalfa saponin extract to hyperlipidemic rats significantly reduced liver TC and increased liver total bile acids (TBA) level. This may be ascribed to the decrease of absorbed cholesterol and fats from the intestine into blood circulation and liver because saponins can form insoluble complexes with dietary cholesterol and inhibit pancreatic lipase, respectively (Vinarova et al 2015). It can be observed that saponins extracted from fenugreek and licorice were effective than those extracted from asparagus and soapwort in lowering triglycerides level in liver of rats administered these plant extracts. 
Table (2) Effect of saponin extracts of Trigonella (TRI), Asparagus (ASP), Saponaria (SAP) and Glycyrrhiza (GLY) on the levels of total cholesterol and triglycerides in liver of rats treated with high cholesterol diet (HCD).

\begin{tabular}{|c|c|c|c|c|c|c|}
\hline Treatment & Control & HCD only & $\begin{array}{l}\text { HCD } \\
+ \text { TRI }\end{array}$ & $\begin{array}{r}\text { HCD } \\
+ \text { ASP }\end{array}$ & $\begin{array}{r}\text { HCD } \\
+ \text { SAP }\end{array}$ & $\begin{array}{l}\text { HCD } \\
+ \text { GLY }\end{array}$ \\
\hline $\begin{array}{c}\text { Total } \\
\text { cholesterol } \\
(\mathrm{mg} / \mathrm{g})\end{array}$ & $\begin{array}{c}3 \\
\pm 0.5^{b}\end{array}$ & $\begin{array}{c}11.8 \\
\pm 0.5^{a}\end{array}$ & $\begin{array}{r}3.7 \\
\pm 0.6^{b}\end{array}$ & $\begin{array}{r} \\
4.1 \\
\pm 0.2^{b}\end{array}$ & $\begin{array}{r}4.4 \\
\pm 0.3^{b}\end{array}$ & 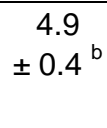 \\
\hline $\begin{array}{l}\text { Triglycerides } \\
(\mathrm{mg} / \mathrm{g})\end{array}$ & $\begin{array}{r}17.3 \\
\pm 1.9^{c}\end{array}$ & $\begin{array}{c}33.4 \\
\pm 1.5^{a}\end{array}$ & $\begin{array}{r}17.2 \\
\pm 1.1^{\mathrm{c}}\end{array}$ & $\begin{array}{r}19.4 \\
\pm 0.4^{\mathrm{b}}\end{array}$ & $\begin{aligned} & 20 \\
\pm & 0.2^{b}\end{aligned}$ & $\begin{array}{r}16.1 \\
\pm 0.6^{\mathrm{c}}\end{array}$ \\
\hline
\end{tabular}

The data are presented as means \pm SE calculated from three replicates.

Different letters refer to significant differences at $(P<0.05)$.

\section{Effect of saponin extracts on the lipid profile in feces of rats affected with hypercholesterol- emia}

Data presented in Table (3) indicate the protective effects of steroidal saponins extracted from fenugreek and asparagus, and triterpenoidal saponins extracted from soapwort and licorice on the lipid profile (total cholesterol and triglycerides) in feces of rats affected with hypercholesterolemia induced by feeding on high cholesterol diet (HCD). The data indicated a significant $(\mathrm{P}<0.05)$ increase in the levels of total cholesterol (TC) and triglycerides (TG) in feces of rats treated with HCD plus various plant extracts compared to negative and positive controls. The inhibition of cholesterol absorption from the intestine, and the inhibition of pancreatic lipase induced by saponin extracts led to decrease of absorbed cholesterol and fats from the intestine into blood circulation and liver, and increase the excretion of cholesterol and fats in feces of rats fed on these plant extracts. These results are in accordance with those obtained by Rashmi and Kaushik (2011) who found that fecal bile acids and cholesterol excretion are increased by fenugreek administration. Shi et al (2014) also reported that total cholesterol and total bile acids (TBA) levels in feces of hyperlipidemic rats were remarkably elevated by alfalfa saponin extract administration. Data presented in the same table illustrate that total cholesterol contents in feces of rats that received steroidal saponins extracted from fenugreek and asparagus were significantly higher than those in feces of rats that received triterpenoidal saponins extracted from soapwort and licorice. Conversely, triglycerides contents in feces of rats that received steroidal saponins extracted from fenugreek and asparagus were significantly lower than those in feces of rats that received triterpenoidal saponins extracted from soapwort and licorice.

Table (3) Effect of saponin extracts of Trigonella (TRI), Asparagus (ASP), Saponaria (SAP) and Glycyrrhiza (GLY) on the levels of total cholesterol and triglycerides in feces of rats treated with high cholesterol diet

\begin{tabular}{|c|c|c|c|c|c|c|}
\hline Treatment & Control & HCD only & $\begin{array}{l}\text { HCD } \\
+ \text { TRI } \\
\end{array}$ & $\begin{array}{r}\text { HCD } \\
+\mathrm{ASP} \\
\end{array}$ & $\begin{array}{r}\text { HCD } \\
+ \text { SAP } \\
\end{array}$ & $\begin{array}{r}\text { HCD } \\
+\mathrm{GLY} \\
\end{array}$ \\
\hline $\begin{array}{c}\text { Total } \\
\text { cholesterol } \\
(\mathrm{mg} / \mathrm{g})\end{array}$ & $\begin{array}{r}6.5 \\
\pm 1.0^{c}\end{array}$ & $\begin{array}{c}9.8 \\
\pm 1.8^{c}\end{array}$ & $\begin{array}{c}51.3 \\
\pm 6.4^{a}\end{array}$ & $\begin{array}{c}46.3 \\
\pm 6.0^{a}\end{array}$ & $\begin{array}{c}40.4 \\
\pm 6.1^{\mathrm{b}}\end{array}$ & $\begin{array}{c}41.1 \\
\pm 6.4^{b}\end{array}$ \\
\hline $\begin{array}{c}\text { Triglycerides } \\
(\mathrm{mg} / \mathrm{g})\end{array}$ & $\begin{array}{r}30.6 \\
\pm 0.4^{c}\end{array}$ & $\begin{array}{r}34.9 \\
\pm 1.9^{\mathrm{c}}\end{array}$ & $\begin{array}{r}58.9 \\
\pm 2.4^{\mathrm{b}}\end{array}$ & $\begin{array}{r}51.9 \\
\pm 4.5^{\mathrm{b}}\end{array}$ & $\begin{array}{c}77.9 \\
\pm 3.2^{\mathrm{a}}\end{array}$ & $\begin{array}{r}68 \\
\pm 9.1^{\mathrm{a}}\end{array}$ \\
\hline
\end{tabular}

The data are presented as means \pm SE calculated from three replicates.

Different letters refer to significant differences at $(P<0.05)$. 


\section{Effect of saponin extracts on the liver profile of rats affected with hypercholesterolemia}

Regarding the protective effects of steroidal saponins extracted from fenugreek and asparagus, and triterpenoidal saponins extracted from soapwort and licorice on the liver profile (AST, ALT, ALP, GGT enzymes) in serum of rats affected with hypercholesterolemia induced by feeding on high cholesterol diet (HCD), data are shown in Table (4). The data showed a significant $(P<0.05)$ increase in the levels of all liver enzymes (AST, ALT, ALP and GGT) of rats treated with HCD only in positive control group compared to negative control group. This may be attributed to that feeding of rats in the positive control group on HCD that also contains high saturated fat (coconut butter) led to accumulation of cholesterol and fats in the liver causing fatty liver. This accumulation of fats in the liver can induce inflammation and necrosis and damage in the liver cells and consequently increase releasing of liver enzymes into blood circulation. The protective effects of various saponin extracts were established by occurring the levels of these enzymes near to their normal values in serum of rats administered these plant extracts. Data presented in the same table demonstrate that the activities of ALP enzyme in serum of rats that received steroidal saponins extracted from fenugreek and asparagus were comparable to those in serum of rats of control group, and frequently lower than those in serum of rats that received triterpenoidal saponins extracted from soapwort and licorice.

Concerning the protective effects of steroidal saponins extracted from fenugreek and asparagus, and triterpenoidal saponins extracted from soapwort and licorice on the liver profile (total bilirubin, TB and total protein, TP) in serum of rats affected with hypercholesterolemia induced by feeding on high cholesterol diet (HCD), data are presented in Table (5). There were no significant $(P<0.05)$ differences in the levels of TB and TP in serum of rats of all treatments compared to negative and positive control groups during the experiment period. Obviously, increasing the levels of various liver enzymes (AST, ALT, ALP and GGT) without change in the levels of other liver function tests such as TB and TP in serum of rats affected with hypercholesterolemia indicate early stage of liver damage whereas liver enzymes as liver function markers are more sensitive parameters than others such as TB and TP for occurrence of inflammation and necrosis in the liver cells owing to accumulation of cholesterol and fats in these cells.

Table 4. Effect of saponin extracts of Trigonella (TRI), Asparagus (ASP), Saponaria (SAP) and Glycyrrhiza (GLY) on the levels of AST, ALT, ALP and GGT enzymes in serum of rats treated with high cholesterol diet (HCD)

\begin{tabular}{|c|c|c|c|c|c|c|}
\hline Treatment & Control & $\begin{array}{l}\text { HCD } \\
\text { only }\end{array}$ & $\begin{array}{l}\text { HCD } \\
+ \text { TRI }\end{array}$ & $\begin{array}{r}\text { HCD } \\
+ \text { ASP } \\
\end{array}$ & $\begin{array}{r}\text { HCD } \\
+ \text { SAP }\end{array}$ & $\begin{array}{r}\text { HCD } \\
+G L Y \\
\end{array}$ \\
\hline $\begin{array}{l}\text { AST } \\
(\mathrm{U} / \mathrm{L})\end{array}$ & $\begin{array}{c}94.6 \\
\pm 4.8^{b}\end{array}$ & $\begin{array}{c}140 \\
\pm 4.9^{a}\end{array}$ & $\begin{array}{c}86.2 \\
\pm 5.1^{b}\end{array}$ & $\begin{array}{c}83.3 \\
\pm 1.4^{b}\end{array}$ & $\begin{array}{c}89.6 \\
\pm 2.3^{b}\end{array}$ & $\begin{array}{r}84.2 \\
\pm 2.9^{b}\end{array}$ \\
\hline $\begin{array}{l}\text { ALT } \\
(\mathrm{U} / \mathrm{L})\end{array}$ & $\begin{array}{c}38.3 \\
\pm 1.5^{b}\end{array}$ & $\begin{array}{c}94.1 \\
\pm 2.5^{a}\end{array}$ & $\begin{array}{c}31.3 \\
\pm 3.0^{b}\end{array}$ & $\begin{array}{c}33.9 \\
\pm 2.6^{b}\end{array}$ & $\begin{array}{r}35.5 \\
\pm 2.1^{b}\end{array}$ & $\begin{array}{r}33.7 \\
\pm 3.7^{b}\end{array}$ \\
\hline $\begin{array}{l}\text { ALP } \\
(\mathrm{U} / \mathrm{L})\end{array}$ & $\begin{array}{r}109.7 \\
\pm 5.7^{c}\end{array}$ & $\begin{array}{c}316.1 \\
\pm 9.8^{a}\end{array}$ & $\begin{array}{r}104.2 \\
\pm 2.6^{c}\end{array}$ & $\begin{array}{r}112.8 \\
\pm 3.4^{c}\end{array}$ & $\begin{array}{r}136.1 \\
\pm 2.0^{b}\end{array}$ & $\begin{array}{r}129.7 \\
\pm 5.7^{b}\end{array}$ \\
\hline $\begin{array}{l}\text { GGT } \\
(\mathrm{U} / \mathrm{L})\end{array}$ & $\begin{array}{r}7.3 \\
\pm 0.3^{b}\end{array}$ & $\begin{array}{c}11.3 \\
\pm 0.3^{a}\end{array}$ & $\begin{array}{c}6.9 \\
\pm 0.3^{b}\end{array}$ & $\begin{array}{r}6.8 \\
\pm 0.4^{b}\end{array}$ & $\begin{array}{l}8.1 \\
\pm 0.4^{b}\end{array}$ & $\begin{array}{r}6.5 \\
\pm 0.1^{b}\end{array}$ \\
\hline
\end{tabular}

The data are presented as means \pm SE calculated from three replicates.

Different letters refer to significant differences at $(\mathrm{P}<0.05)$. 
Table 5. Effect of saponin extracts of Trigonella (TRI), Asparagus (ASP), Saponaria (SAP) and Glycyrrhiza (GLY) on the levels of total protein and total bilirubin in serum of rats treated with high cholesterol diet (HCD)

\begin{tabular}{|c|c|c|c|c|c|c|}
\hline Treatment & Control & HCD only & $\begin{array}{c}\text { HCD } \\
+ \text { TRI }\end{array}$ & $\begin{array}{c}\text { HCD } \\
+ \text { ASP }\end{array}$ & $\begin{array}{c}\text { HCD } \\
+ \text { SAP }\end{array}$ & $\begin{array}{c}\text { HCD } \\
+ \text { GLY }\end{array}$ \\
\hline $\begin{array}{c}\text { Total } \\
\text { protein } \\
\text { (g/dl) }\end{array}$ & $\begin{array}{c}6.48 \\
\pm 0.5^{\mathrm{a}}\end{array}$ & $\begin{array}{c}6.43 \\
\pm 0.3^{\mathrm{a}}\end{array}$ & $\begin{array}{c}6.38 \\
\pm 0.3^{\mathrm{a}}\end{array}$ & $\begin{array}{c}6.81 \\
\pm 0.2^{\mathrm{a}}\end{array}$ & $\begin{array}{c}6.25 \\
\pm 0.4^{\mathrm{a}}\end{array}$ & $\begin{array}{c}6.67 \\
\pm 0.6^{\mathrm{a}}\end{array}$ \\
$\begin{array}{c}\text { Total } \\
\text { bilirubin } \\
(\mathrm{mg} / \mathrm{dl})\end{array}$ & $\begin{array}{c}0.14 \\
\pm 0.01^{\mathrm{a}}\end{array}$ & $\begin{array}{c}0.32 \\
\pm 0.06^{\mathrm{a}}\end{array}$ & $\begin{array}{c}0.13 \\
\pm 0.01^{\mathrm{a}}\end{array}$ & $\begin{array}{c}0.12 \\
\pm 0.02^{\mathrm{a}}\end{array}$ & $\begin{array}{c}0.11 \\
\pm 0.02^{\mathrm{a}}\end{array}$ & $\begin{array}{c}0.13 \\
\pm 0.02^{\mathrm{a}}\end{array}$ \\
\hline
\end{tabular}

The data are presented as means $\pm \mathrm{SE}$ calculated from three replicates.

Different letters refer to significant differences at $(P<0.05)$.

\section{Effect of saponin extracts on the heart profile of rats affected with hypercholesterolemia}

The protective effects of steroidal saponins extracted from fenugreek and asparagus, and triterpenoidal saponins extracted from soapwort and licorice on the cardiac profile (CPK and LDH enzymes) in serum of rats affected with hypercholesterolemia induced by feeding on high cholesterol diet (HCD) are illustrated in Table (6). The results demonstrated a significant $(\mathrm{P}<0.05)$ increase in the levels of CPK and $\mathrm{LDH}$ in serum of rats treated with HCD only in positive control group compared to negative control group. This may be ascribed to feeding of rats in the positive control group on HCD that also contains high saturated fat (coconut butter) compared to feeding of rats in the negative control group on a normal diet containing corn oil. This feeding led to accumulation of cholesterol and fats in form of LDL in coronary arteries and caused myocardial infarction. The latter can induce necrosis and damage in the heart cells and consequently increase releasing of cardiac enzymes (CPK and LDH) into blood circulation. The protective effects of various saponin extracts were evidenced by appearance the levels of CPK and LDH enzymes near to their normal values in serum of rats administered these plant extracts.

Table 6. Effect of saponin extracts of Trigonella (TRI), Asparagus (ASP), Saponaria (SAP) and Glycyrrhiza (GLY) on the levels of CPK and LDH enzymes in serum of rats treated with high cholesterol diet (HCD)

\begin{tabular}{|c|c|c|c|c|c|c|}
\hline Treatment & Control & HCD only & $\begin{array}{r}\text { HCD } \\
+ \text { TRI } \\
\end{array}$ & $\begin{array}{r}\text { HCD } \\
+ \text { ASP } \\
\end{array}$ & $\begin{array}{r}\text { HCD } \\
+ \text { SAP } \\
\end{array}$ & $\begin{array}{r}\text { HCD } \\
+ \text { GLY }\end{array}$ \\
\hline $\begin{array}{l}\text { CPK } \\
(\mathrm{U} / \mathrm{L})\end{array}$ & $\begin{array}{c}650.3 \\
\pm 46.1^{b}\end{array}$ & $\begin{array}{c}1010 \\
\pm 25.1^{a}\end{array}$ & $\begin{aligned} & 660 \\
\pm & 30.3^{b}\end{aligned}$ & $\begin{array}{c}594.6 \\
\pm 36.7^{b}\end{array}$ & $\begin{array}{c}674 \\
\pm 24.1^{b}\end{array}$ & $\begin{array}{r}619.6 \\
\pm 48.1^{b}\end{array}$ \\
\hline $\begin{array}{l}\mathrm{LDH} \\
(\mathrm{U} / \mathrm{L})\end{array}$ & $\begin{array}{r}850 \\
\pm 28.0^{b}\end{array}$ & $\begin{array}{r}1456.6 \\
\pm 35.2^{a}\end{array}$ & $\begin{array}{r}757.6 \\
\pm 37.0^{b}\end{array}$ & $\begin{array}{c}817.3 \\
\pm 21.3^{b}\end{array}$ & $\begin{array}{r}802.3 \\
\pm 15.3^{b}\end{array}$ & $\begin{array}{r}841 \\
\pm 51.0^{b}\end{array}$ \\
\hline
\end{tabular}

The data are presented as means \pm SE calculated from three replicates.

Different letters refer to significant differences at $(P<0.05)$.

\section{Effect of saponin extracts on the blood sugar} level of rats affected with hypercholesterolemia

Dealing with the protective effects of steroidal saponins extracted from fenugreek and asparagus, and triterpenoidal saponins extracted from soapwort and licorice on the blood sugar of rats affected with hypercholesterolemia induced by feeding on high cholesterol diet (HCD), data are shown in Table (7). The data showed a significant $(P<0.05)$ increase in the levels of serum glucose of rats treated with HCD only in positive control group $(161.3 \pm 7.3 \mathrm{mg} / \mathrm{dl})$ compared to negative control group $(110.6 \pm 9.2 \mathrm{mg} / \mathrm{dl})$. This may be attributed to that feeding of rats in the positive control group on HCD that also contains high saturated fat 
(coconut butter) led to accumulation of cholesterol and fats in the liver causing fatty liver. This accumulation of fats in the liver may increase insulin resistance in the liver cells and consequently increase the level of blood sugar in the positive control group. These results are in agreement with those obtained by Sil et al (2013). The protective effects of various saponin extracts were established by occurrence the glucose levels near to their normal values in serum of rats administered these plant extracts.

Table 7. Effect of saponin extracts of Trigonella (TRI), Asparagus (ASP), Saponaria (SAP) and Glycyrrhiza (GLY) on the levels of glucose in serum of rats treated with high cholesterol diet (HCD)

\begin{tabular}{|c|c|c|c|c|c|c|}
\hline Treatment & Control & HCD only & $\begin{array}{c}\text { HCD } \\
+ \text { TRI }\end{array}$ & $\begin{array}{c}\text { HCD } \\
+ \text { ASP }\end{array}$ & $\begin{array}{c}\text { HCD } \\
+ \text { SAP }\end{array}$ & $\begin{array}{c}\text { HCD } \\
+ \text { GLY }\end{array}$ \\
\hline $\begin{array}{c}\text { Glucose } \\
(\mathrm{mg} / \mathrm{dl})\end{array}$ & $\begin{array}{c}110.6 \\
\pm 9.2^{\mathrm{b}}\end{array}$ & $\begin{array}{c}161.3 \\
\pm 7.3^{\mathrm{a}}\end{array}$ & $\begin{array}{c}119.6 \\
\pm 3.4^{\mathrm{b}}\end{array}$ & $\begin{array}{c}124.3 \\
\pm 6.1^{\mathrm{b}}\end{array}$ & $\begin{array}{c}111.6 \\
\pm 12.4^{\mathrm{b}}\end{array}$ & $\begin{array}{c}125 \\
\pm 1.1^{\mathrm{b}}\end{array}$ \\
\hline
\end{tabular}

The data are presented as means \pm SE calculated from three replicates.

Different letters refer to significant differences at $(P<0.05)$.

7. Effect of saponin extracts on the kidney profile of rats affected with hypercholesterolemia

Data presented in Table (8) elucidate the protective effects of steroidal saponins extracted from fenugreek and asparagus, and triterpenoidal saponins extracted from soapwort and licorice on the renal profile (urea, creatinine and uric acid) in serum of rats affected with hypercholesterolemia induced by feeding on high cholesterol diet (HCD). The data elucidated non significant $(\mathrm{P}<0.05)$ differences in the levels of these parameters in serum of rats for all treatments compared to negative and positive controls. It means that hypercholesterolemia induced by feeding on HCD did not cause any adverse effects on kidney tissues during the experiment period (6 weeks).

Table 8. Effect of saponin extracts of Trigonella (TRI), Asparagus (ASP), Saponaria (SAP) and Glycyrrhiza (GLY) on the levels of urea, creatinine and uric acid in serum of rats treated with high cholesterol diet

\begin{tabular}{|c|c|c|c|c|c|c|}
\hline Treatment & Control & HCD only & $\begin{array}{c}\text { HCD } \\
+ \text { TRI }\end{array}$ & $\begin{array}{c}\text { HCD } \\
+ \text { ASP }\end{array}$ & $\begin{array}{c}\text { HCD } \\
+ \text { SAP }\end{array}$ & $\begin{array}{c}\text { HCD } \\
+ \text { GLY }\end{array}$ \\
\hline Urea & 61.6 & 76.9 & 61.4 & 68.1 & 64.1 & 58.7 \\
(mg/dl) & $\pm 5.8^{\mathrm{a}}$ & $\pm 12.5^{\mathrm{a}}$ & $\pm 2.4^{\mathrm{a}}$ & $\pm 5.5^{\mathrm{a}}$ & $\pm 1.3^{\mathrm{a}}$ & $\pm 3.1^{\mathrm{a}}$ \\
& & & & & & \\
Creatinine & 0.74 & 0.95 & 0.69 & 0.79 & 0.7 & 0.72 \\
(mg/dl) & $\pm 0.05^{\mathrm{a}}$ & $\pm 0.03^{\mathrm{a}}$ & $\pm 0.01^{\mathrm{a}}$ & $\pm 0.02^{\mathrm{a}}$ & $\pm 0.01^{\mathrm{a}}$ & $\pm 0.07^{\mathrm{a}}$ \\
Uric acid & $1.16^{\mathrm{a}}$ & 1.88 & 1.37 & $1.41^{\mathrm{a}}$ & 1.44 & 1.39 \\
(mg/dl) & $\pm 0.04^{\mathrm{a}}$ & $\pm 0.06^{\mathrm{a}}$ & $\pm 0.01^{\mathrm{a}}$ & $\pm 0.2^{\mathrm{a}}$ & $\pm 0.03^{\mathrm{a}}$ & $\pm 0.01^{\mathrm{a}}$ \\
\hline
\end{tabular}

The data are presented as means \pm SE calculated from three replicates.

Different letters refer to significant differences at $(P<0.05)$.

\section{Effect of saponin extracts on the liver histol- ogy of rats affected with hypercholesterolemia}

The protective effects of steroidal saponins extracted from fenugreek and asparagus, and triterpenoidal saponins extracted from soapwort and licorice on the liver histology of rats affected with hypercholesterolemia induced by feeding on high cholesterol diet (HCD) are illustrated in Figures (1-12). Liver of rats from negative control group showed the normal histological structure of hepatic lobule (Fig. 1). However, liver of rats from positive control group which affected with hypercholesterolemia revealed fatty pattern change of hepatocytes (Fig. 2) and sinusoidal leukocytosis (Fig. 3). Liver of rats treated with asparagus 
showed slight activation of kupffer cells (Fig. 4), whereas most examined sections from this group revealed no histopathological changes (Fig. 5). Moreover, liver of rats treated with licorice showed no histopathological changes (Fig. 6) except cytoplasmic vacuolization of centrilobular hepatocytes in few examined sections (Fig. 7). Liver of rats treated with soapwort showed binucleation of hepatocytes (Fig. 8), whereas most cases from this revealed no histopathological changes (Fig. 9). Some examined sections from rats treated with fenugreek revealed cytoplasmic vacuolization of hepatocytes (Fig. 10) and slight activation of kupffer cells (Fig. 11) whereas other sections showed no histopathological changes (Fig. 12).

Finally, steroidal saponins (C27) extracted from fenugreek and asparagus, and triterpenoidal saponins (C30) extracted from soapwort and licorice exhibited great protective effects against hypercholesterolemia induced by feeding of rats on HCD. The protective effects of various saponin extracts were established by occurring the levels of TC, TG,

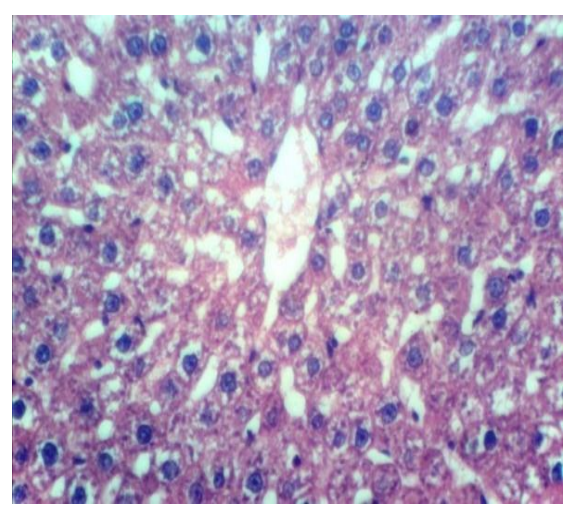

Fig. 1. Liver of rat from negative control group showing the normal histological structure of hepatic lobule.

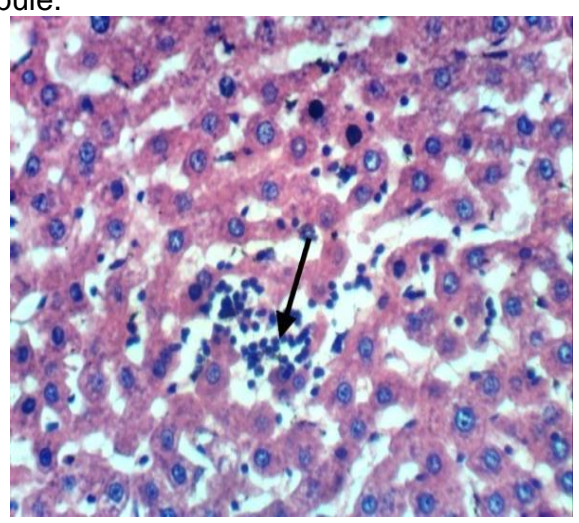

Fig. 3. Liver of rat from positive control group showing sinusoidal leukocytosis.
HDL, LDL, VLDL, CPK, LDH, ALT, AST, ALP, GGT and glucose near to their normal values in serum of rats administered these plant extracts compared to negative and positive controls. The protective effects of various saponin extracts were also established by obtaining the levels of TC and TG near to their normal values in liver of rats administered these plant extracts. The lowering effect of saponin extracts against hypercholesterolemia may be due to the inhibition of cholesterol absorption from the intestine owing to formation of insoluble complexes between cholesterol and saponins which was proved in this study through increase the excretion of cholesterol and fats in feces of rats fed on these plant extracts compared to the positive control group. Histological examinations showed lower contents of fats in liver tissues of the rats treated with various saponin extracts compared to the positive control group. Both of steroidal and triterpenoidal saponins exhibited approximately the same efficiency in their protective effects against hypercholesterolemia.

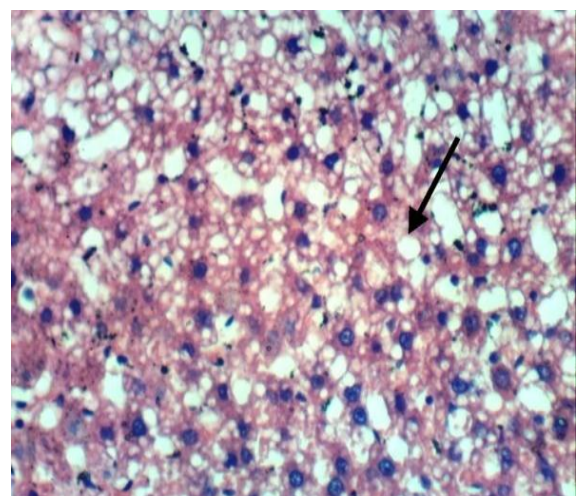

Fig. 2. Liver of rat from positive control group showing fatty change of hepatocytes.

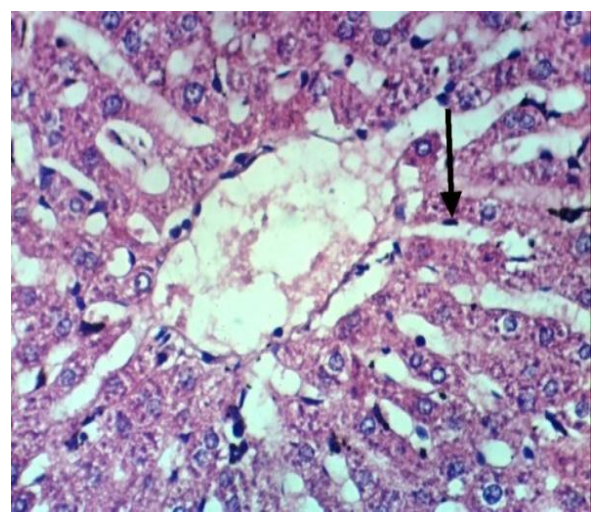

Fig. 4. Liver of rat treated with asparagus showing slight activation of kupffer cells. 


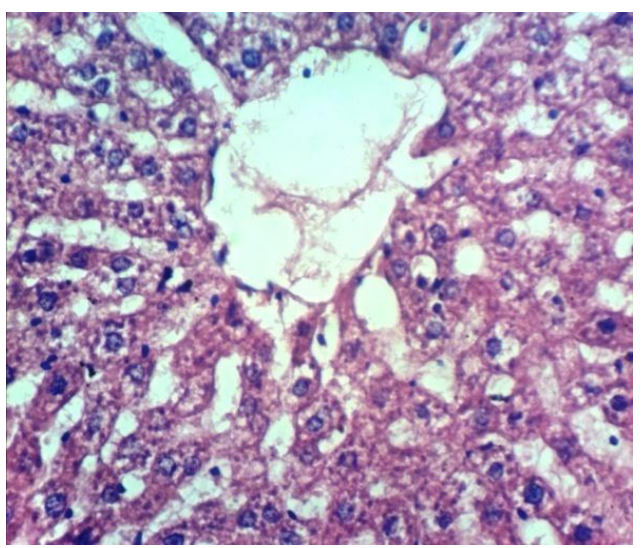

Fig. 5. Liver of hyperlipidemic rat treated with asparagus showing no histopathological changes.

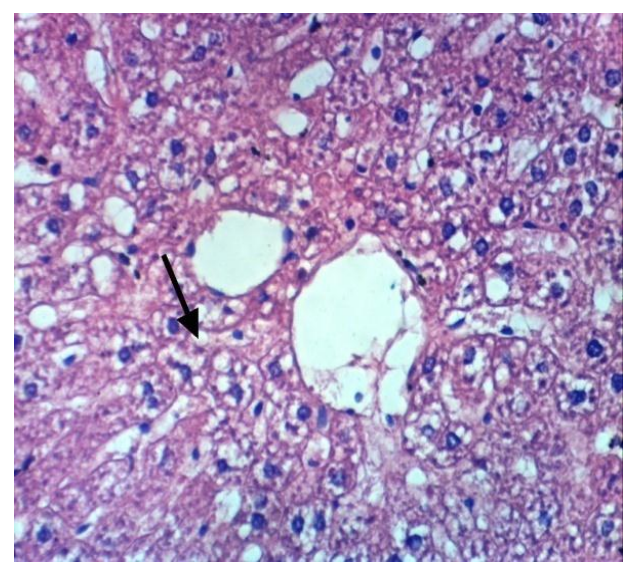

Fig. 7. Liver of rat treated with licorice showing cytoplasmic vacuolization of hepatocytes.

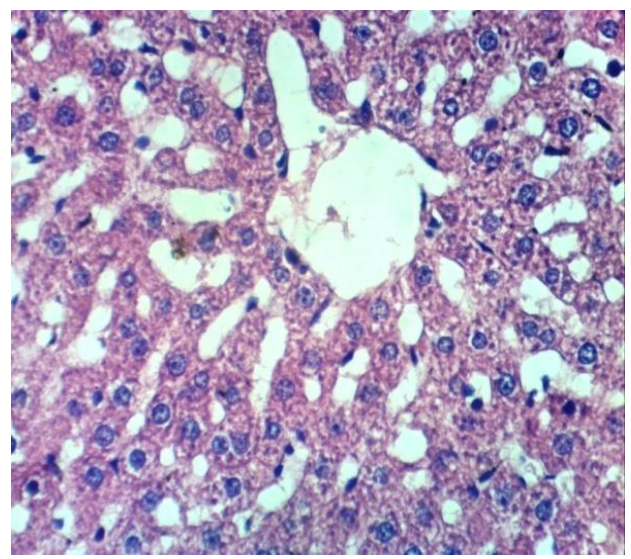

Fig. 9. Liver of hyperlipidemic rat treated with soapwort showing no histopathological changes.

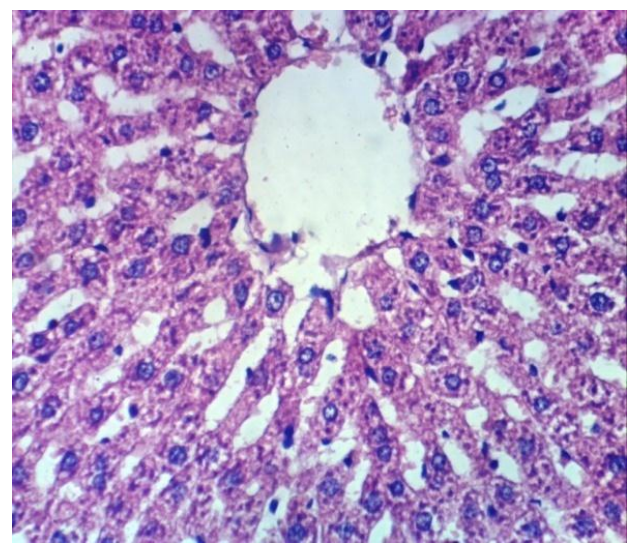

Fig. 6. Liver of hyperlipidemic rat treated with licorice showing no histopathological changes.

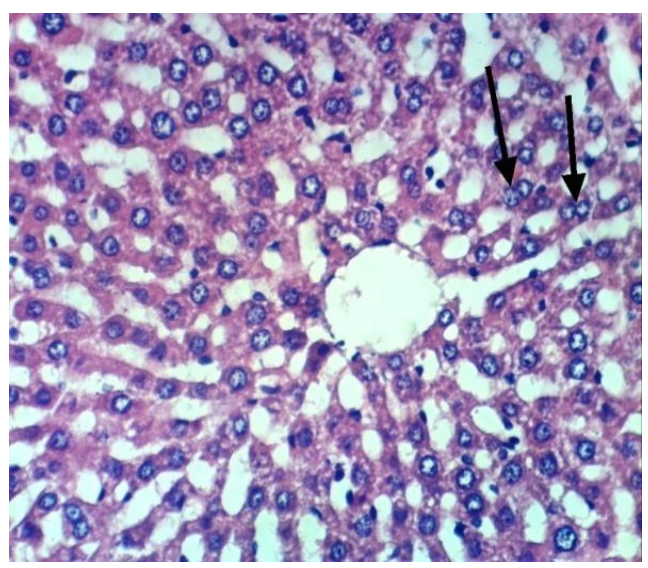

Fig. 8. Liver of rat treated with soapwort showing binucleation of hepatocytes.

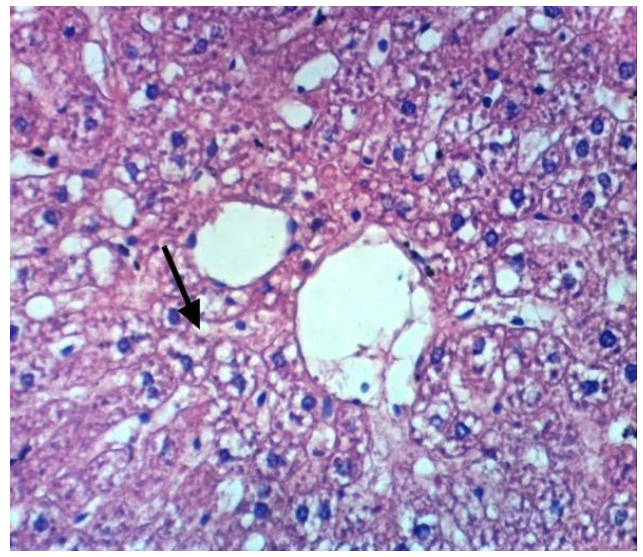

Fig. 10. Liver of rat treated with fenugreek showing cytoplasmic vacuolization of hepatocytes. 


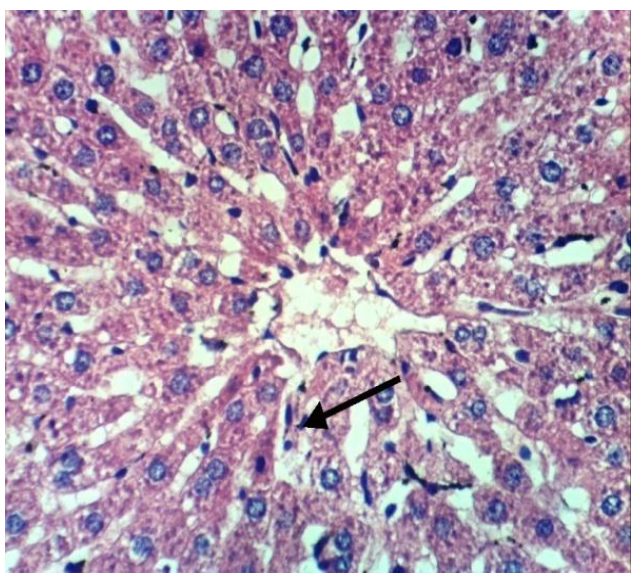

Fig. 11. Liver of rat treated with fenugreek showing slight activation of kupffer cells.

\section{REFERENCES}

Afrose S., Hossain M.S., Maki T. and Tsujii H. 2010. Hypocholesterolemic response to Karaya saponin and Rhodobacter capsulatus in broiler chickens. Asian-Australasian J. of Animal Sci., 23(6), 733.

Al-Qarawi A., Rahman H.A. and Mougy S.E. 2001. Hepatoprotective activity of Liquorice in rat liver injury models. J. Herb. Sp. Med., 8, 714.

Arystanova T., Irismetov M. and Sophekova A. 2001. Chromatographic determination of glycyrrhizinic acid in Glycyrrhiza glabra Preparation. Chem. Nat. Com., 37, 89-91.

Basch E., Ulbricht C., Kuo G., Szapary P. and Smith M. 2003.. Therapeutic applications of fenugreek. Alternative Medicine Review, 8(1), 20-27.

Bowers L.D. and Wong E.T. 1980. Kinetic serum creatinine assays. II. A critical evaluation and review. Clin. Chem., 26, 555.

Ceyhun-Sezgin, A.E. and Artik N. 2010. Determination of Saponin Content in Turkish Tahini Halvah by Using HPLC. Adv. J. Food Sci. Technol., 2, 109-115.

Dito W.R. 1979. Lactate dehydrogenase: A brief review. In: Griffiths JC, ed. Clinical Enzymology. New York: masson publishing USA, 18 p.

Fæste C.K., Namork E. and Lindvik H. 2009. Allergenicity and antigenicity of fenugreek (Trigonella foenum-graecum) proteins in

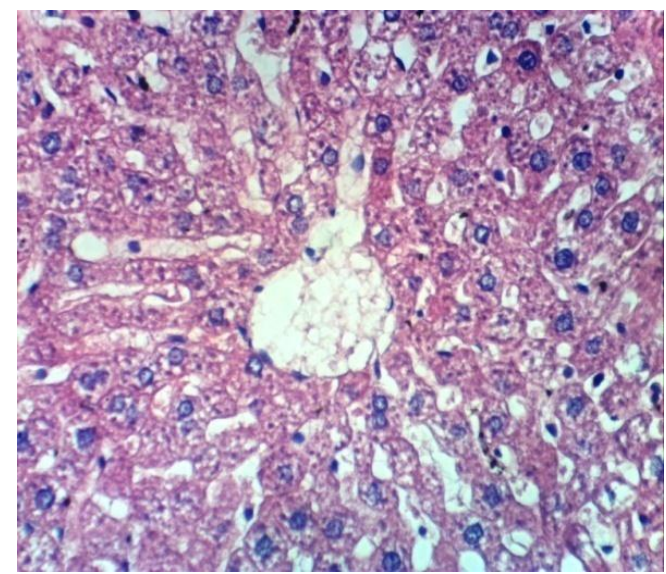

Fig. 12. Liver of hyperlipidemic rat treated with fenugreek showing no histopathological changes.

foods. J. of Allergy and Clinical Immunology, 123(1), 187-194.

Folch J., Lees M. and Sloane Stanley G.H. 1957. A simple method for the isolation and purification of total lipids from animal tissues. J. Biol. Chem., 226(1), 497-509.

Fukai T., Cai B.S., Maruno K., Miyakawa Y., Konishi M. and Nomura T. 1998.. An isoprenylated flavanone from Glycyrrhiza glabra and rec-assay of licorice phenols1. Phytochemistry, 49(7), 2005-2013.

Gornall A.G., Bardawill C.J. and David M.M. 1949. Determination of serum proteins by means of the biuret reaction. $\mathbf{J}$. of Biol. Chem., 177(2), 751-766.

Han L.K., Zheng Y.N., Xu B.J., Okuda H. and Kimura Y. 2002. Saponins from Platycodi Radix ameliorate high fat diet induced obesity in mice. The J. of Nutrition, 132(8), 2241-2245.

Hostettmann K. and Marston A. 1995. Saponins: Chemistry and Pharmacology of Natural Products. Cambridge University Press, New York, USA.

Høstmark A.T., Lunde M.S.H. and Eilertsen E. 2010. Does an acid load promote liver desaturases and increase serum lipids? Clinical Reviews and Opinions, 2(1), 008-016.

IFCC, 1989. Methods for the measurement of catalytic concentration of enzymes. Part 7: IFCC method for creatine kinase. JIFCC; 1, 130-139. 
Izzo A.A., Di Carlo G., Borrelli F. and Ernst E. 2005. Cardiovascular pharmacotherapy and herbal medicines: the risk of drug interaction. Int. J. of Cardiology, 98(1), 1-14.

Jani R., Udipi S.A. and Ghugre P.S. 2009. Mineral content of complementary foods. The Indian J. of Pediatrics, 76(1), 37-44.

Jenkins K.J. and Atwal A.S. 1994. Effects of dietary saponins on fecal bile acids and neutral sterols, and availability of vitamins $A$ and $E$ in the chick. J. of Nutritional Biochemistry, 5(3), 134-137.

Jung D.H. and Parekh A.C. 1970. An improved reagent system for the measurement of serum uric acid. Clinical Chemistry, 16(3), 247-250.

Khatta, K.F. and Simpson T.J. 2010. Effect of gamma irradiation on the antimicrobial and free radical scavenging activities of glycyrrhiza glabra root. Radiat. Phys. Chem., 79, 507-512.

Kumar P., Kale R.K., McLean P. and Baquer N.Z. 2012. Antidiabetic and neuroprotective effects of Trigonella foenum-graecum seed powder in diabetic rat brain. Prague Med Rep, 113(1), 33-43.

Makni M., Fetoui H., Gargouri N.K., Garoui E.M., Jaber H., Makni J., Boudawarara T. and Zeghal N. 2008. Hypolipidemic and hepatoprotective effects of flax and pumpkin seed mixture rich in $\omega-3$ and $\omega-6$ fatty acids in hypercholesteremic rats. Food and Chem. Toxicology, 46, 3714-3720.

Malloy H.T. and Evelyn K.A. 1937. The determination of bilirubin with the photoelectric colorimetric method. J. Biol. Chem., 119(2), 481490.

Marrelli M., Conforti F., Araniti F. and Statti G.A. 2016. Effects of saponins on lipid metabolism: a review of potential health benefits in the treatment of obesity. Molecules, 21(10), 1404.

Mgowan M.W., Artiss J.D., Standbergh D.R. and Zak B. 1983. A peroxidase-coupled method for colorimetric determination of serum triglycerides. Clin. Chem., 29, 538-552.

Murlidhar M. and Goswami T.K. 2012. A review on the functional properties, nutritional content, medicinal utilization and potential application of fenugreek. J. of Food Processing and Technology, 3(9), 2157-7110.

NCEPR 1995. National Cholesterol Education Program Recommendation for measurement of High-Density Lipoprotein Cholesterol. Executive summary. Clin. Chem., 41, 1427-1433.
Oakenfull D.G. 1986. Aggregation of saponins and bile acids in aqueous solution. Australian J. of Chem., 39(10), 1671-1683.

Persijn J.P. and Van der Slik W. 1976. A new method for the determination of $Y$-glutamyltransferase in serum. Clinical Chemistry and Laboratory Medicine, 14(1-12), 421-428.

Rao P.U., Sesikeran B., Rao P.S., Naidu A.N., Rao V.V. and Ramachandran E.P. 1996. Short term nutritional and safety evaluation of fenugreek. Nutrition Research, 16(9), 14951505.

Rashmi Y. and Kaushik R. 2011. A study of phytochemical Constituents and pharmacological actions of trigonella foenum-graecum: A review. Int. J. of Pharmacy \& Technology, 3(2),1022-1028.

Reeves P.G., Nielsen F.H. and Fahey G.C. 1993. AIN-93 purified diets for laboratory rodents: final report of the American Institute of Nutrition ad hoc writing committee on the reformulation of the AIN-76A rodent diet. The J. of Nutrition, 123(11), 1939-1951.

Roeschlau P., Bernt E. and Gruber W. 1974. Enzymatic determination of total cholesterol in serum (author's transl). Zeitschrift fur klinische Chemie und Klinische Biochemie, 12(9), 403-407.

Ross I.A. 2001. Glycyrrhiza glabra. Medicinal plants of the world. Chemical constituents, traditional and modern medicinal uses, Humana Press, Totowa, N. J., 2, 191-240.

Satoskar R.S., Bhandarkar S.D. and Ainapure S.S. 2003. Hypolipidemic drugs. In: Pharmacology and Pharmacotherapeutics, 18th ed. Popular Prakashan, Mumbai, India 567-575.

Senapaty S., Yadav R.P., Paul N.S. and Chavan R. 2014. Evaluation of in-vitro pancreatic lipase inhibitory activity of fenugreek seeds extracts. Int. J. of Pharmaceutical Sci. and Health Care, 4(4), 1-7.

Shi Y., Guo R., Wang X., Yuan D., Zhang S., Wang J., Yan X. and Wang C. 2014. The regulation of alfalfa saponin extract on key genes involved in hepatic cholesterol metabolism in hyperlipidemic rats. Plos one, 9(2), p.e88282.

Sidhu G.S. and Oakenfull D.G. 1986. A mechanism for the hypocholesterol-aemic activity of saponins. British J. of Nutrition, 55(3), 643649. 
Sil R., Ray D. and Chakraborti A.S. 2013. Glycyrrhizin ameliorates insulin resistance, hyperglycemia, dyslipidemia and oxidative stress in fructose-induced metabolic syndrome- $X$ in rat model. Indian J. of Experimental Biology 51, 129-138.

Snedecor G.M. and Cochran W.G. 1980. Statistical methods, Sixth Edition, lowa State Univ. press, Amer. lowa, USA.

Srivastava A. and Shivanandappa T. 2006. Hepatoprotective effect of the aqueous extract of the roots of Decalepis hamiltonii against ethanol-induced oxidative stress in rats. Hepatology Research, 35(4), 267-275.

Tietz, N.W. 1990. Clinical guide to laboratory tests. $2^{\text {nd }}$ ed. Philadelphia, Pa: WB Saunders Company, 566-570.

Tietz, N.W. 1995. Clinical guide to laboratory tests. $3^{\text {rd }}$ ed. Philadelphia, Pa: WB Saunders Company, 130-138.

Uemura T., Goto T., Kang M.S., Mizoguchi N., Hirai S., Lee J.Y. and Tsuge N. 2011. Diosgenin, the Main Aglycone of Fenugreek, Inhibits LXRa Activity in HepG2 Cells and Decreases Plasma and Hepatic Triglycerides in Obese Diabetic Mice-3. The J. of Nutrition, 141(1), 17-23.
Vázquez-Castilla S., De la Puerta R., GarciaGimenez M.D., Fernández-Arche M.A. and Guillén-Bejarano R. 2013. Bioactive constituents from "triguero" asparagus improve the plasma lipid profile and liver antioxidant status in hypercholesterolemic rats. Int. J. of Molecular Sci., 14(11), 21227-21239.

Vejtorp M., Christensen M.S., Vejtorp L. and Larsen J.F. 1986. Serum lipoprotein changes in climacteric women induced by sequential therapy with natural estrogens and medroxyprogesterone acetate or norgestrel. Acta obstetricia et gynecologica Scandinavica, 65(5), 391-395.

Vinarova L., Vinarov Z., Damyanova B., Tcholakova S., Denkov N. and Stoyanov S. 2015. Mechanisms of cholesterol and saturated fatty acid lowering by Quillaja saponaria extract, studied by in vitro digestion model. Food \& Function, 6(4), 1319-1330.

Young D.S. 1990. Effects of drugs on clinical laboratory tests. $3^{\text {rd }}$ ed. 3, 6-12.

Zulet M.A., Barber A., Garcin H., Higueret P. and Martinez J.A. 1999. Alterations in carbohydrate and lipid metabolism induced by a diet rich in coconut oil and cholesterol in a rat model. J. of the American College of Nutrition, 18(1), 36-42. 
مجلة اتحاد الجامعات العربية للعلوم الزراعية ، جامعة عين شمس ، القاهرة ، مصر

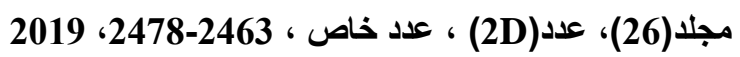

Website: http://strategy-plan.asu.edu.eg/AUJASCI/

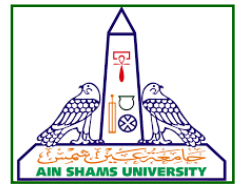

تأثير مستخلصات الصابونين على خفض الكوليسترول فى حيوانات التجارب

[181]

\author{
أمانى محمد محمد على - مجدى فؤاد توفيق - محمد سيد صلاح هيكل - ممدو ابو \\ ممدوح أبومسلم تاج الاين \\ قسم الكيمياء الحيوية - كلية الزراعة - جامعة عين شمس - ص.ب 68 - حدائق شبرا 11241 - القاهرة - مصر
}

*Corresponding author: Amany.mohamed.am23@gmail.com

Received 9 July, 2018

Accepted 15 August, 2018

والمنخفضة جدا فى الكثافة ونشاط إنزيمات كرياتين

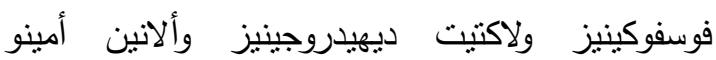

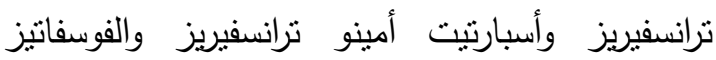
القلوى وجاما جلوتامايل ترانسفيريز والجلوكوز وانخفاض

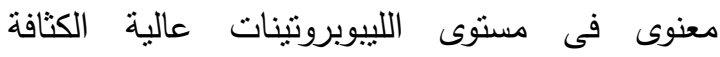

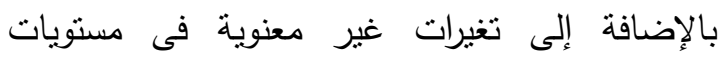
البيليروبين الكلى والبروتين الكلى واليوريا والكرياتينين فئين

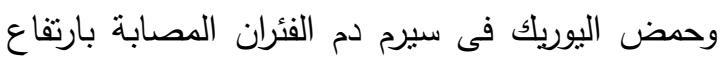

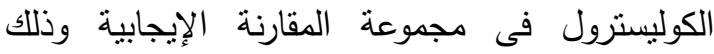
بالمقارنة مع مجموعة المقارنة السلبية. ثبت الإنبانية التأثنر

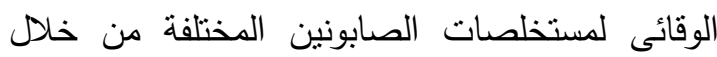
الانخفاض فى مستوى كل من الكوليسترول الكلى لئى

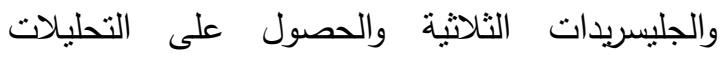

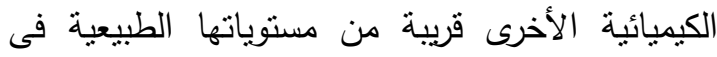

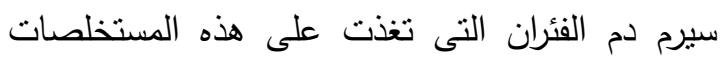
النباتية. أنثارت النتائج أيضاً إلى ألى أن مسنويات النيات

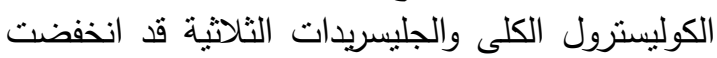

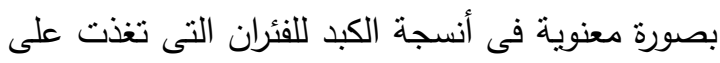

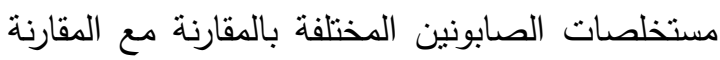

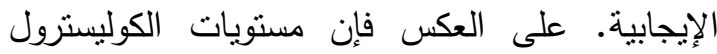

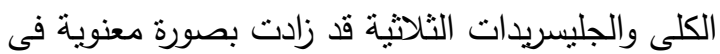

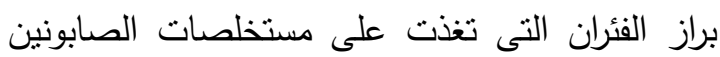

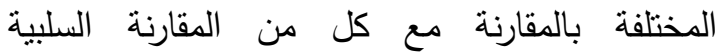

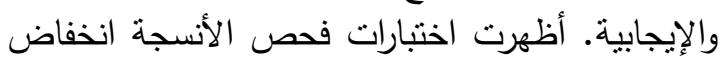

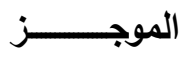

تم إصابة فئران التجارب بارتفاع الكوليسترول عن

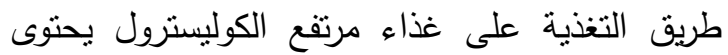
على كوليسترول بنسبة 1\% ع وأملاح المرارة بنسبة 0.25 وزبدة جوز الهند بنسبة 15\% وذلك لتينة التقييم التأثير الوقائى للصابونينات الإستيرويدية المستخلصة

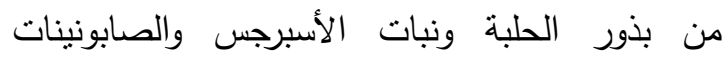

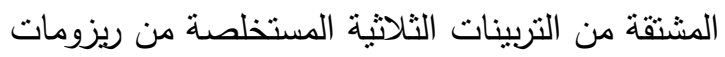
العرقسوس وعرق الحلاوة. تم تقسيم الفئران إلى 6

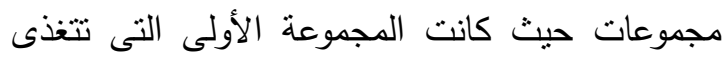
على علف عادى هى مجموعة المقارنة السلبية

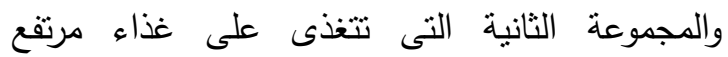
الكوليسترول بدون مستخلصات نباتية هى المئي المقارنة

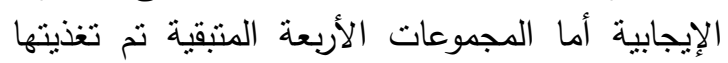
على غذاء مرتفع الكوليسترول مع المستخلصات النباتية الإنية الأربعة بصورة منفصلة بواسطة أنبوبة المعدة بجرعة الكبنة

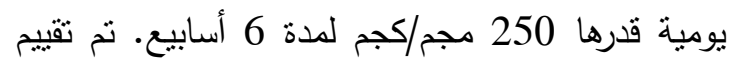

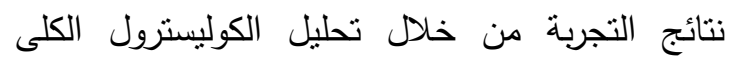
والجليسريدات الثثلاثية فى كل من الدام والكبد والبراز لكل المجموعات بالإضافة إلى تحليلات الدام الأخرى

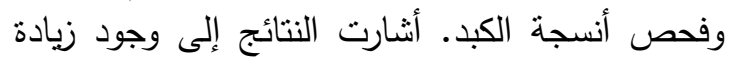
معنوية فى مستويات كل من الكوليسترول الكلى

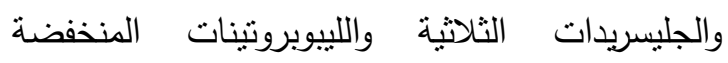


إلى تثبيط امنصاص الكوليسترول فى الأمعاء الذى في إلى إلى

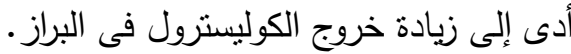

الكلمات الدالة: الأسبرجس، الحلبة، زيادة الكوليسترول

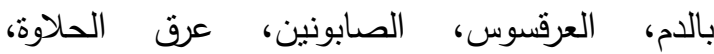
استيرويدى، شبيه التربينات الثناثية
محتوى الدهون فى أنسجة الكبد للفئران التى تغذت على

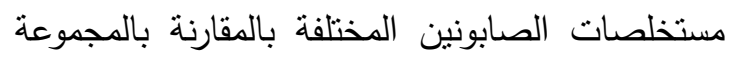
الإيجابية. أظهرت كل من الصابونينات الإستيرويدية والمشتقة من التربينات الثلاثية نفس الكفاءة فى تأثثراتها الوقائية ضد ارتفاع الكوليسترول. ربما يرجع التأثير الوقائى المخفض للكوليسترول لمستخلصات الصابونين 